\title{
Ocular teratogens: old acquaintances and new dangers
}

A Tandon ${ }^{1}$ and A Mulvihill ${ }^{2}$

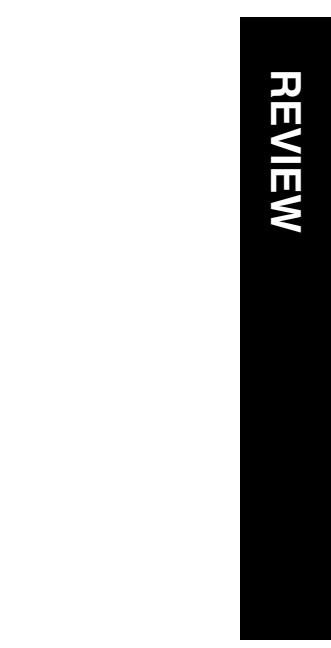

\begin{abstract}
Recent research into animal studies has contributed significantly to understanding the pathophysiology of some well-known teratogens, such as alcohol. Techniques, such as positron emission tomography (PET) and retinal synaptogenesis studies, have helped determine the specific areas in the developing brain and ocular structures, which are targeted by various teratogens. In this article, we also highlight a few newer agents, such as benzodiazepines, with potential for ocular malformation and morbidity in the developing foetus.

Eye (2009) 23, 1269-1274; doi:10.1038/eye.2009.30; published online 20 February 2009
\end{abstract}

Keywords: Teratogen; Embryology; PAX6; Fetal alcohol syndrome; Retinal synaptogenesis; Neurotropic

\section{Introduction}

Teratology is the study of the causes and biological processes leading to abnormal development and birth defects and of the appropriate measures for prevention. Although genetics and other branches of medical science have justifiably received great attention in recent years for their huge contribution to our understanding of disease and malformations, teratology has been somewhat neglected. We feel, however, that teratology deserves greater attention for its continuing contribution to congenital malformations. This review article aims to familiarise the clinician with the ocular manifestations of teratogenic agents, enabling diagnosis and avoiding unnecessary investigations. The principal findings are summarised in Table 1.

The potential for certain environmental agents to cause foetal malformation was known to physicians, even in ancient times. The Bible, for instance warns against drinking wine or strong drink during pregnancy to have healthy children. ${ }^{1}$ Several thousand years ago,
Charaka ${ }^{2}$, the famous ayurvedic physician of ancient India wrote a treatise on organogenesis during pregnancy that recognised the teratogenic effects of alcohol.

Embryology forms the reference science for teratology. Ocular embryogenesis was first detailed by Ida Mann during 1920s-1960s. ${ }^{3}$ Malformations of the eyes are among the most common causes of childhood visual impairment in developed countries. ${ }^{4,5}$ Although good antenatal care is available for expectant mothers in the developed world, lack of awareness of the effect of environmental agents, such as drugs, (both therapeutic and recreational) still results in foetal malformations.

Modern teratology began with the observation in the 1920s that radiation could cause foetal malformation, such as cataract. In 1941, Gregg6 observed that rubella infection during early pregnancy produced ocular anomalies, such as congenital cataract.

Thalidomide, an antianxiety and antiemetic drug, that was used widely by pregnant women in the 1960s, was recognised as being responsible for severe teratogenic malformations. Lenz $z^{7}$ observed 50 children whose mothers had consumed thalidomide during pregnancy. A significant number of thalidomide children had ocular motility disorders, such as Duane's retraction syndrome. ${ }^{8}$ Careful investigation of children with thalidomide malformations suggested that the motility abnormalities were due to a discrete insult occurring 20-24 days after conception. Later in the 1960s, the teratogenic effects of alcohol were confirmed. ${ }^{9}$

\section{Ocular embryogenesis}

The cranial neural crest cells contribute mainly to the morphogenesis of the eye and face, and are particularly vulnerable to teratogenic insult. ${ }^{1}$ The entire development process is finely controlled by an innate plan, programmed by several genes, of which PAX 6 is the most
${ }^{1}$ Department of

Ophthalmology, Kettering

General Hospital,

Edinburgh, UK

${ }^{2}$ Princess Alexandra Eye Pavilion, Edinburgh, UK

Correspondence: A Tandon, Ophthalmology,

Kettering General Hospital, Rothwell Road,

Kettering,

Northants NN16 8UZ, UK

Tel: + 44131536 1674;

Fax: +441315361574

E-mail: anamikatan@ gmail.com

Received: 27 September 2007

Accepted in revised form: 22 January 2009

Published online: 20 February 2009 
Table 1 Ocular teratogens

\begin{tabular}{|c|c|c|c|}
\hline Agent & Principal ocular malformations & Principal systemic malformations & Possible mechanism of action \\
\hline \multicolumn{4}{|l|}{ Substance abuse } \\
\hline Alcohol & $\begin{array}{l}\text { ONH, coloboma, nystagmus, cataract, } \\
\text { microphthalmos }\end{array}$ & $\begin{array}{l}\text { Mild mental retardation, } \\
\text { hyperactivity }\end{array}$ & Nerve cell apoptosis \\
\hline Opioids & $\begin{array}{l}\text { Nystagmus, reduced vision, delayed } \\
\text { visual maturation }\end{array}$ & Microcephaly & Midbrain toxicity \\
\hline Benzodiazepines & $\begin{array}{l}\text { Nystagmus, reduced vision, delayed } \\
\text { visual maturation }\end{array}$ & & Midbrain toxicity \\
\hline Cocaine & $\begin{array}{l}\text { Prolonged eyelid oedema, optic nerve } \\
\text { abnormalities, delayed visual } \\
\text { maturation }\end{array}$ & Strucrural brain malformations & CNS serotonin transport \\
\hline \multicolumn{4}{|l|}{ Prescription medications } \\
\hline Thalidomide & $\begin{array}{l}\text { Duanes/ocular motility disorders, } \\
\text { lacrimation }\end{array}$ & Limb malformations & \\
\hline Anticonvulsants & Myopia, prominent long eye lashes & $\begin{array}{l}\text { Neural tube defects, congenital } \\
\text { heart disease }\end{array}$ & $\begin{array}{l}\text { Folate metabolism, } \\
\text { collagen } 2 \text { production }\end{array}$ \\
\hline Vitamin A & Microphthalmia, hypertelorism & $\begin{array}{l}\text { Retinoic acid embryopathy, } \\
\text { craniofacial anomalies }\end{array}$ & \\
\hline \multicolumn{4}{|l|}{ TORCHS infections } \\
\hline Toxoplasmosis & Retinochoroiditis & $\begin{array}{l}\text { Microcephaly, intracranial } \\
\text { calcification }\end{array}$ & $\begin{array}{l}\text { Direct viral damage, } \\
\text { reduced mitosis }\end{array}$ \\
\hline Rubella & $\begin{array}{l}\text { Cataract, glaucoma, microphthalmos, } \\
\text { chorioretinitis }\end{array}$ & $\begin{array}{l}\text { Deafness, congenital heart } \\
\text { disease }\end{array}$ & $\begin{array}{l}\text { Direct viral damage, } \\
\text { reduced mitosis }\end{array}$ \\
\hline CMV & $\begin{array}{l}\text { Cataract, microphthalmos, } \\
\text { chorioretinitis, ONH }\end{array}$ & $\begin{array}{l}\text { Thrombocytopenia, } \\
\text { splenomegaly, IUGR }\end{array}$ & $\begin{array}{l}\text { Vasculitis, extensive tissue } \\
\text { necrosis }\end{array}$ \\
\hline HSV & $\begin{array}{l}\text { Cataract, microphthalmos, } \\
\text { chorioretinitis, ONH }\end{array}$ & $\begin{array}{l}\text { Microcephaly, intracranial } \\
\text { calcification }\end{array}$ & \\
\hline Syphilis & Interstitial keratitis, cataract, glaucoma & $\begin{array}{l}\text { Renal, hepatic manifestations, } \\
\text { generalised lymphadenopathy }\end{array}$ & \\
\hline Varicella & $\begin{array}{l}\text { Blepharoconjunctivitis, keratitis, } \\
\text { chorioretinitis, optic atrophy }\end{array}$ & Cortical visual impairment & $\begin{array}{l}\text { Direct viral damage, } \\
\text { reduced mitosis }\end{array}$ \\
\hline $\begin{array}{l}\text { Lymphocytic } \\
\text { choriomeningitis virus }\end{array}$ & $\begin{array}{l}\text { Chorioretinopathy, nystagmus, } \\
\text { oesotropia, microphthalmos, cataract }\end{array}$ & & \\
\hline \multicolumn{4}{|l|}{ Metabolic disorders } \\
\hline Diabetes mellitus & Optic nerve hypoplasia & Neural tube defects & $\begin{array}{l}\text { Reduced } P A X 3 \text { gene } \\
\text { expression }\end{array}$ \\
\hline Radiation & Cataract & Widespread anomalies & Effect on DNA \\
\hline
\end{tabular}

important one. In a mouse model, it has been known to play a key role in both the lens and retinal development through interaction with various transcription factors, regulating cell proliferation and differentiation. PAX 6 mutations are associated with abnormalities in all the ocular tissues, such as lens, cornea, retina, and iris. Also, ectopic expression of PAX 6 in insects and frogs has shown eye formation in these sites. Similar studies in other model organisms coupled with genetic information from human patients with ocular maldevelopments have helped establish its selective role in eye development. PAX 6 dosage of expression is critical. For instance, overexpression causes micro-ophthalmia in transgenic mice. Both environmental and genetic factors may affect this, thus affecting neuronal induction, migration, and differentiation during early embryogenesis. ${ }^{10}$ The extent of damage to the growing embryo depends on the timing of insult, its dose, and its species specificity. ${ }^{11,12}$

\section{Foetal alcohol syndrome (FAS)}

FAS is the most extreme manifestation of prenatal alcohol exposure and is characterised by the presence of signs in each of three categories; ${ }^{13}$ first, there is prenatal and/or postnatal growth retardation. Second is the central nervous system involvement. Third is the characteristic facial dysmorphism with at least two of the following: microcephaly, microphthalmia, short palpebral fissures, poorly developed philtrum, thin upper lip, deformed pinna, and flattening of maxillary area. 
Miller et $a l^{14}$ described nine patients with typical features of FAS, five of whom had strabismus and three who had ptosis. A possible intriguing feature of FAS is that anterior segment anomalies seemed to predominate in Afro-Caribbean populations, ${ }^{15}$ whereas posterior segment abnormalities predominate in mainly Caucasian populations. Stromland and Ksiazek. ${ }^{16}$ reported that most ocular anomalies occurred in the fundus, ranging from malformations of several structures to discrete lesions. The most frequent finding was unilateral or bilateral optic nerve hypoplasia (48\%), followed by abnormally tortuous retinal vessels and foveal hypoplasia. ${ }^{16}$ Other features included microphthalmos, phthisis, coloboma, nystagmus, cataract, and persistent foetal vasculature. ${ }^{17}$ Ocular signs are such a frequent finding in children with FAS that an ophthalmological examination is advised in making this diagnosis. The electroretinogram may show deficits in retinal sensitivity; decreased amplitude, and increased latency, especially for rod responses. ${ }^{18}$ In a study of 11 individuals with FAS and developmental delay, optic nerve hypoplasia was present in $91 \%$, reduced visual acuity in $91 \%$, and abnormal MRI brain scans in all.

A conservative estimate of the incidence of FAS in the Western world is 0.33 per 1000 live births. ${ }^{19}$

\section{The pathophysiology of FAS}

Teratogenic studies in animal models have shown that ethanol affects the major neurotransmitter systems, glutamate, and $\gamma$-amino butyric acid (GABA) during a critical period of development, causing developing nerve cells to die en masse by apoptosis. The window of vulnerability coincides with synaptogenesis (brain growth-spurt period) that is confined to postnatal life in rodents, but which encompasses the third trimester and first several years of life in humans. Retinal synaptogenesis in humans begins around late first or early second trimester. In rodent studies, during a similar period, a single ethanol intoxication lasting several hours triggers a massive wave of apoptosis of neurons at all levels of the visual system from retina to the visual cortex within hours of ethanol administration, consistent with a primary insult to ganglion cells. Exposure of the human foetus to ethanol at any time during second or third trimester may similarly entail risk of neurons being destroyed at some level of the visual system; retina, lateral geniculate nucleus, superior colliculus, or visual cortex. ${ }^{20}$ In a mammalian model of FAS in mouse embryo, embryos exposed to high ethanol were smaller and less advanced in development than were the embryos in the control group, and showed craniofacial abnormalities, such as a fusion defect of the neural tube. ${ }^{21}$
The optic nerve hypoplasia seen in FAS was until recently thought to result from optic nerve dysmyelination. The finding of acute apoptotic neuro degeneration, however, indicates that the changes may be secondary to the degeneration of retinal ganglion cells. ${ }^{22}$ It is difficult to determine the exact amount of maternal alcohol ingestion during pregnancy, but binge drinking can cause periodic high blood levels throughout pregnancy. Therefore, ocular structures are susceptible throughout term.

\section{Cocaine}

Cocaine can easily access the foetal circulation, and the developing visual system is vulnerable to cocaine exposure. ${ }^{23}$ Prenatal cocaine exposure has been associated with developmental delay and structural brain abnormalities, such as septo-optic dysplasia, porencephaly, and bilateral cortical infarcts. ${ }^{24}$ Newborns exposed to cocaine in utero may show marked vascular disruption in the retina manifested as superficial and deep haemorrhages. Although morphologically similar to retinal haemorrhages related to birth trauma, these haemorrhages take longer to reabsorb. ${ }^{25}$

Good et $a l^{26}$ reported 13 cocaine-exposed infants with optic nerve abnormalities, delayed visual maturation, and prolonged eyelid oedema. The eyelid oedema was so severe and prolonged in some cases as to be sight threatening. The authors hypothesised that the easy access of cocaine to foetal circulation, together with its neurotropic effects, help explain the optic nerve anomalies and delayed visual maturation. In infants, any of these eye abnormalities and especially the combination of them mandates a careful investigation for cocaine abuse. ${ }^{26}$

\section{Opiates}

Heroin and methadone are the chief opiates associated with foetal exposure. In the United Kingdom, most pregnant heroin addicts are now on methadone programmes.

As opiate withdrawal can be more harmful to the developing foetus than continued drug exposure, no efforts are usually made to wean methadone-dependent women during pregnancy. In the neonatal period, withdrawal symptoms (neonatal abstinence syndrome) may occur and are most severe among methadoneexposed infants. ${ }^{27}$ Until recently, however, little had been reported about the effects of opiates on the visual system. Gailliard and Borruat ${ }^{28}$ reported transient horizontal pendular nystagmus in five neonates who received morphine for neonatal abstinence syndrome. A toxic effect of morphine on the midbrain was suggested to 
explain this phenomenon. Recently, we have reported nystagmus in 14 children with a history of exposure to opiates and/or benzodiazepines during pregnancy. ${ }^{29}$ All children had reduced visual acuity and most had developmental delay and delayed visual maturation. None of the children had a specific neurological diagnosis or seizure disorder, and their electrophysiological examinations, such as electroretinogram and visual-evoked potential, were normal. The nystagmus and associated clinical features were particularly associated with the combined use of opiates and benzodiazepines.

Recent research using positron emission tomography (PET) has revealed a high number of opiate receptors in the human central nervous system. ${ }^{30}$ Labelled fentanil and morphine have been used to identify these receptors, especially $\mu$-opioid receptors. ${ }^{31}$ It has been shown that $\mu$-opioid receptors are upregulated in cocaine and alcohol as nystagmus occurs in children exposed to various drugs in utero. Concurrent use of benzodiazepines may enhance the effects of opiates making nystagmus more likely in babies born to mothers who abuse both drug types as diazepam counters morphine tolerance by stopping the upregulation of central nervous system $\mu$-opioid in animal models. ${ }^{32}$

\section{Foetal anticonvulsant syndrome}

Distinct congenital malformations, including several ocular defects, have been well described as foetal anticonvulsant syndrome. Although there are differences in phenotypes after exposure to sodium valproate, carbamezapine, and phenytoin, significant overlap of features exists. Foetal valproate syndrome is characterised by the presence of epicanthic folds, medially deficient eyebrows, shallow nasal bridge with anteverted nares, and trignocephaly. Wyszynski et al ${ }^{33}$ reported that the greatest risk for foetal malformations, such as neural tube defects, happened with valproate exposure more than phenytoin or carbamazepine. A dose-dependent effect for valproate was also shown and supported its role as a teratogen. Observations in a small series of children with prenatal valproate exposure suggested high incidence of early onset myopia. This was confirmed in a study by Glover et $a l^{34}$ of 58 children with known prenatal exposure to anticonvulsant drugs, either as valproate monotherapy or in combination with other drugs. A significantly high incidence of myopia and strabismus was seen. It was suggested that the drugs' effect on folic acid metabolism might be responsible for the neural tube defects seen in these children. In vitro studies have also shown valproate causing increased production of type 1 collagen, but decreased production of type 2 collagen found in vitreous. It is possible that valproate results in myopia because of its effect on collagen 2 production.

\section{Diabetes mellitus}

Diabetic pregnancy, despite the improved metabolic control, is still a strong risk factor for alterations in foetal development, particularly in patients with a tendency to brittle glycaemia during the first trimester. Congenital malformations, including neural tube defects, are significantly increased in the offspring of diabetic mothers and have been seen in experimental organisms, such as rodents. In a mouse model of diabetic pregnancy, expression of $P A X 3$, a gene encoding the transcription factor required for neural tube development, was shown to be significantly decreased, and was associated with increased frequency of neural tube defects. The proposed mechanism is increased oxidative stress in the embryo in maternal diabetes, which in turn inhibits the expression of PAX3 gene. $^{35,36}$

The most common ocular malformation in babies born to diabetic mothers is optic nerve hypoplasia. Keeping fasting glucose levels in the first trimester below $5.8 \mathrm{mmol} / 1$ and postprandial glucose levels below $9.1 \mathrm{mmol} / 1$ can contribute to decreasing the number of foetal malformations in pregestational diabetes mellitus pregnancy. ${ }^{37}$

\section{Intrauterine infections}

The developing embryo may be exposed to maternal infections, such as TORCH infections (ie, toxoplasmosis, rubella, cytomegalovirus, and herpes simplex, and syphilis) ${ }^{38-41}$ and lymphocyte choriomenigitis. ${ }^{42}$ These may spread either by the haematogenous route or by ascending maternal genitourinary tract or even during the delivery process. The damage to the embryo may be limited only to the developmental stage at which infection occurs or may continue into postnatal life.

Different pathogens causing intrauterine infections can produce a similar spectrum of clinical signs. They may, therefore, be indistinguishable on morphological features alone (see Table 1 for details).

\section{Vitamin A}

Hale $^{43}$ showed that vitamin A deficiency in female pigs produced anophthalmos and microphthalmos in its offspring. Since then, both hypo- and hypervitaminosis A have been known to be associated with foetal developmental defects. Isotretinoin or accutane is a vitamin A analogue used for treatment of severe acne. Its use during pregnancy, causing high levels of vitamin A in an expectant mother, is teratogenic and is associated 
with a collection of foetal malformations known as retinoic acid embryopathy. ${ }^{44}$ Retinoids, the synthetic derivates of vitamin $\mathrm{A}$, have a key role on cellular differentiation and developmental tissue specificity. Their effects are mediated by nuclear receptors, which transactivate homeobox genes. In animals models, they all have been shown to induce similar foetal malformations dependent on the dose and the duration of exposure, affecting the craniofacial structures, foetal neural development, and postnatal sensorineural functioning. ${ }^{45}$ In a case report of acitrenin embryopathy, a vitamin A analogue, an infant with prenatal exposure showed microcephaly, epicanthal folds, and neurodevelopmental delay. ${ }^{46}$

Interestingly, several characteristics of FAS are similar to the teratogenic effects of retinoic acid exposure. It has been suggested that FAS may result from ethanolinduced alteration in endogenous retinoic acid synthesis, leading to abnormal embryonic concentrations. In an animal model study of Xenopus embryo, it was shown that with ethanol exposure during late blastula and early gastrula stage, the formation and function of the embryonic organiser was disrupted due to a reduction in retinoic acid levels. Ethanol is antagonistic to retinol and to retinal conversion of retinoic acid. The authors suggested that this mechanism may be in part responsible for the craniofacial features seen in FAS. ${ }^{47}$ Retinoic acid and ethanol have also been shown to reverse each others effect in studies on isolated neuroblastoma cells. ${ }^{48}$

\section{What else is out there?}

The recreational use of drugs, such as ecstasy and cannabis, is widespread, and although we have no definite information as to their potential as teratogens, the possibility must be at least considered. These agents are used because they exert effects on the central nervous system and can all be reasonably presumed to have the potential to damage the developing nervous system. The effects of cannabinoids on the nervous system are not fully understood, and they may in fact have some neuroprotective functions. ${ }^{49}$ The popular dance drug ecstasy is neurotoxic to central serotonergic neurons in laboratory animals, and possibly also in humans..$^{50}$

In recent years, several studies have reported alterations of serotonergic transmission and neuropsychiatric abnormalities in ecstasy users. However, the prevalence of polydrug use makes it difficult to isolate the specific effects of ecstasy alone. ${ }^{51}$ A study from Toronto on pregnant women using ecstasy found that they were generally young and single, and had a clustering of risk factors that could compromise the pregnancy and foetus. ${ }^{52}$
Ophthalmologists must be aware of the potential teratogenicity of both illicit and prescribed drugs. There is a very urgent need to more widely publicise the adverse effects of these drugs, not only among those who use them but also the carers of these young adults. It is also important for the clinicians to suspect possible exposure to substance abuse in neonates in appropriate settings possibly avoiding the need for extensive and often invasive investigations to establish the diagnosis.

\section{References}

1 Book of Judges 13:7, Old Testament: King James version.

2 Charaka . Charak Samhita, Vimanasthan, chapter I: translated by PV Sharma, Chaukhamba Orientalia Publishers: Varanasi, 1981, 305.

3 Mann I. Development of the Human Eye. Grune and Stratton Inc: New York, 1964.

4 Goggin M, O'Keefe M. Childhood blindness in the Republic of Ireland: a national survey. Br J Ophthalmol 1991; 75(7): 425-429.

5 Foster A. Childhood blindness. Eye 1988; 2(suppl): S27-S36.

6 Gregg NM. Congenital cataracts following German measles in the mother. Trans Ophthal Soc Austr 1944; 3: 35-46.

7 Lenz W. Thalidomide and congenital abnormalities (letter). Lancet 1962; 1: 45.

8 Miller MT, Stromland K. Ocular motility and thalidomide embryopathy. J Pediatr Ophthalmol Strabismus 1991; 28(1): $47-54$.

9 Jones KL, Smith DW. Recognition of the fetal alcohol syndrome in early infancy. Lancet 1973; 2(7836): 999-1001.

10 Hever AM, Williamson KA, van Heynigen V. Developmental malformations of the eye: the role of PAX6, SOX2 and OTX2. Clin Genet 2006; 69(6): 459-470.

11 Wilson JG, Fraser FC. Handbook of teratology, Vol. 2, pp 23-66, Plenum Press: New York, 1977.

12 Lamache MA. Communications: Reflexions sur la descendance des alcooliques. Bull Acad Nat Medecine 1967; 151: 517-521.

13 Daniels M, Evans MA. Effect of maternal alcohol consumption on foetal and newborn development. Fed Proc 1980; 39: 846.

14 Miller M, Israel J, Cuttone J. Fetal alcohol syndrome. J Paediatr Ophthal Strabismus 1984; 21: 8-18.

15 Miller M, Epstein R, Sugar J, Pinchoff BS, Sugar A, Gammon JA et al. Anterior segment anomalies associated with the fetal alcohol syndrome. J Paediatr Ophthal Strabismus 1984 21: 8-18.

16 Stromland K, Ksiazek TG. Ocular involvement in the fetal alcohol syndrome. Acta Ophthalmol 1985; 63(suppl): 171.

17 Rosett H, Ksiazek TG. A clinical perspective of the fetal alcohol syndrome. Alcohol Clin Exp Res 1980; 4: 119-122.

18 Hug TE, Fitzgerald KM. Clinical and Electroretinographic findings in Fetal Alcohol Syndrome. J AAPOS 2000; 4(4): 200-204.

19 Young NK. Effects of alcohol and other drugs on children. J Psychoactive Drugs 1997; 29(1): 23-42.

20 Tenkova T, Yound C, Dikranian K, Labruyere J, Olney JW. Ethanol-induced apoptosis in the developing visual system during synaptogenesis. IOVS 2003; 44: 2809-2817. 
21 Yamada Y, Nagase T, Nagase M, Koshima I. Gene expression changes of sonic hedgehog signaling cascade in a mouse embryonic model of fetal alcohol syndrome. J Craniofac Surg 2005; 16(6): 1055-1061, discussion 1062-1063.

22 Pinazo-Duran MD, Renau-Piqueras J, Guerri C.

Developmental changes in the optic nerve related to ethanol consumption in pregnant rats: analysis of the

ethanolexposed optic nerve. Teratology 1993; 48(4): 305-322.

23 Silva-Araujo A, Tavares MA. Development of the eye after gestational exposure to cocaine. Vascular disruption in the retina of rats and humans. Ann NY Acad Sci 1996; 801: 274-288.

24 Dominguez R, Aguirre Vila-Coro A, Slopis JM, Bohan TP. Brain and ocular abnormalities in infants with in utero exposure to cocaine and other street drugs. Am J Dis Child 1991; 145(6): 688-695.

25 Silva-Araujo A, Tavares MA, Patacao MH, Carolino RM. Retinal hemorrhages associated with in utero exposure to cocaine. Experimental and clinical findings. Retina 1996; 16(5): 411-418.

26 Good WV, Ferriero DM, Golabi M, Kobori LA. Abnormalities of the visual system in infants exposed to cocaine. Ophthalmology 1992; 99(3): 341-346.

27 Chiriboga CA. Fetal alcohol and drug effects. Neurologist 2003; 9(6): 267-279.

28 Gaillard MC, Borruat FX. New finding: transitory horizontal pendular nystagmus secondary to neonatal abstinence syndrome. Klin Monatsbl Augenheilkd 2002; 219(4): 317-319.

29 Mulvihill A, Cackett P, George N, Fleck B. Nystagmus secondary to drug exposure in utero. Br J Ophthalmol 2007; 91(5): 613-615.

30 Sprenger T, Berthele A, Platzer S, Boecker H, Tölle TR. What to learn from in vivo opioidergic brain imaging? Eur J Pain 2005; 9(2): 117-121.

31 Gorelick DA, Kim YK, Benchief B, Boyd SJ, Nelson R, Copersino $\mathrm{M}$ et al. Imaging brain mu-opioid receptors in abstinent cocaine users. Biol Psychiatry 2005; 57(12): 1573-1582.

32 Tejwani GA, Sheu MJ, Sribanditmongkol P, Satyapriya A. Inhibition of morphine tolerance and dependence by diazepam and its relation to mu-opioid receptors in the rat brain and spinal cord. Brain Res 1998; 797(2): 305-312.

33 Wyszynski DF, Nambisan M, Surve T, Alsdorf RM, Smith CR, Holmes LB. Antiepileptic drug pregnancy registry. increased rate of major malformations in offspring exposed to valproate during pregnancy. Neurology 2005; 64: 961-965.

34 Glover SJ, Quinn AG, Barter P, Hart J, Moore SJ, Dean JC et al. Ophthalmic findings in the anticonvulsant syndrome. Ophthalmol 2002; 109: 942-947.

35 Phelan SA. A role for Pax3 in maternal diabetes-induced neural tube defects, and characterization of DNA sequences which mediate Pax3 binding and transactivation. Dissertation Abstracts International 1997; 58-05B: 2280.

36 Chang TI, Horal M, Jain SK, Wang F. Oxidant regulation of gene expression and neural tube development. Diabetologia 2003; 46(4): 538-545.

37 Wender-Ozegowska E, Wroblewska K, Zawiejska A, Pietryga M, Szczapa J, Biczysko R. Threshold values of maternal blood glucose in early diabetic pregnancy - prediction of fetal malformations. Acta Obstetricia et Gynecologica Scandinavica 2005; 84(1): 17-25.

38 Kodjikian L, Wallon M, Fleuty J, Denis P, Binquet C, Peyron $\mathrm{F}$ et al. Ocular manifestations in congenital toxoplasmosis. Graefes Arch Clin Exp Ophthalmol 2006; 244(1): 14-21.

39 Wolff SM. The ocular manifestations of congenital rubella: A prospective study of 328 cases of congenital rubella. J Ped Ophthalmol Strabismus 1973; 10: 101.

40 Coats DK, Demmler GJ, Paysse EA, Du LT, Libby C. Ophthalmologic findings in children with congenital cytomegalovirus infection. JAAPOS 2000; 4: 110-116.

41 Reynolds JD, Griebel M, Mallory S, Steele R. Congenital herpes simplex retinitis. Am J Ophthalmol 1986; 102(1): 33-36.

42 Mets MB, Barton LL, Khan AS, Ksiazek TG. Lymphocytic choriomeningitis virus: an underdiagnosed cause of congenital chorioretinitis. Am J Ophthalmol 2000; 130(2): 209-215.

43 Hale FJ. The relation of vitamin A to anophthalmos in pig. Am J Ophthalmol 1935; 18: 1087.

44 Guirgis MF, Wong AMF, Tychsen L. Congenital restrictive external ophthalmoplegia and gustatory epiphora associated with fetal isoretinoin toxicity. Arch Ophthalmol 2002; 120(8): 1094-1095.

45 Marx J, Naudé H, Pretorius E. The effects of hypo- and hypervitaminosis a and its involvement in fetal nervous system development and post-natal sensorimotor functioning - A review. Br Dev Disabil 2006; 52(102, part 1): 47-64.

46 Pablo B, Vanesa L, Ruben B, Miriam P, Liliana A. Acitretin embryopathy: a case report. Birth Defects Res A Clin Mol Teratol 2004; 70(10): 831-833.

47 Yelin R, Schyr RB, Kot H, Zins S, Frumkin A, Pillemer G et al. Ethanol exposure affects gene expression in the embryonic organizer and reduces retinoic acid levels. Dev Biol 2005; 279(1): 193-204.

48 Zachman RD, Grummer MA. The interaction of ethanol and vitamin A as a potential mechanism for the pathogenesis of fetal alcohol syndrome. Alcohol Clin Exp Res 1998; 22(7): P1544-P1556.

49 Molina-Holgado F, Pinteaux E, Moore JD, Molina-Holgado E, Guaza C, Gibson RM et al. Endogenous interleukin-1 receptor antagonist mediates antiinflammatory and neuroprotective actions of cannabinoids in neurons and glia. J Neurosci 2003; 23(16): 6470-6474.

50 Campbell NG, Koprich JB, Kanaan NM, Lipton JW. MDMA administration to pregnant Sprague-Dawley rats results in its passage to the fetal compartment. Neurotoxicol Teratol 2006; 28(4): 459-465.

51 Gouzoulis-Mayfrank E, Daumann J. The confounding problem of polydrug use in recreational ecstasy/MDMA users. J Psychopharmacol 2006; 20(2): 188-193.

52 Ho E, Karimi-Tabesh L, Koren G. Characteristics of pregnant women who use ecstasy (3, 4-methylenedioxymethamphetamine). Neurotoxicol Teratol 2001; 23(6): 561-567. 